\title{
Introducing the Fournal of Public Policy
}

\section{The Editor}

Ideas are the stock in trade of social scientists; practical problems are the stock in trade of government. The Fournal of Public Policy is intended to bring together the social scientist's concern with theoretical knowledge, and the practitioner's concern with concrete difficulties. We intended to do so by publishing articles that use concepts derived from any of the social sciences to illuminate a significant problem of contemporary governments.

Public policy is focussed on problems; it attempts to integrate the complementary outlooks of university-based researchers and policymakers caught up in the complexities of government. The difference in outlook is symbolised by the way in which academics define problems in disciplinary terms economics, political science, or sociology, whereas governments are organized around the provision of substantive goods and services - education, health, transportation, defence, and so forth. A good study in public policy should use social science concepts to penetrate more deeply into a problem, and also link the issue at hand with more general theories of the policy process.

Good problems, like good ideas, know few boundaries. The main concerns of government are intrinsically interdisciplinary; hence, the analysis of public policy can combine elements from political science, public administration, economics, sociology, law and also history. No social scientist can expect to cover all these disciplines equally well. But a good study of public policy should avoid assumptions that are naive in the context of the policy process, even if they may be commonplace in restricted quarters of the academic world.

Two tests can be applied to a study of public policy. The first is: does it clearly raise a significant question? It may concern a familiar issue worrying every government, or a concern that ought to be given more attention. If so, does the study then adduce evidence relevant to the question and consider the further implications of this evidence? The methodology chosen to generate evidence should follow from the problem at hand, and the conclusions should be related to problems of the policy process, and not confined to problems in the abstract.

Good ideas are portable: they shed light on many different problems of government. For example, Pressman and Wildavsky's classic study of Implementation is not so much a discussion of urban economic aid, but an 
analysis of a generic problem of public policy. One test of an article for publication here is that the author should show to what extent findings are generalizable from one policy area to another. We cannot hope to cover every policy field in detail: what we can do is publish articles drawing upon research in one policy area that are relevant to many.

Good social science is portable too: it abstracts ideas of broad relevance from specific national contexts. As an international journal, we feel a special obligation to make authors differentiate carefully between conclusions specific to one nation at one point in time, and conclusions that can still be relevant after crossing the Atlantic in either direction. We encourage the submission of articles that explicitly consider public policy in a comparative manner: we also want each article, whatever its geographical focus, to have something to say to readers from a variety of national perspectives facing public policy questions.

Any Journal freshly launched in the 1980 s should be open to new ideas and to new formats for discussing problems. We particularly invite contributions that may fall athwart conventional academic criteria of length or format - but remain high in quality. In this first issue, an article by Richard Rose confronts contemporary complaints about big government by asking what, if anything, is wrong with it? He shows by analysing the components of his model of government what possible pathologies might result. Grant Jordan's study of iron triangles, issue networks and corporatism asks why different metaphors for the policy process have become popular on opposite sides of the Atlantic. It shows what they have in common - and how they differ because of cross-national differences in political institutions. Fred Wirt approaches the study of professions, typically analysed from a sociological standpoint, with a number of pertinent political questions. Alt and Chrystal's analysis of public expenditure seeks explanations for this important concern of government which stand up better than those offered by a number of models which have achieved wide currency. Writing (and rewriting) is itself an integral part of the craft of policy analysis, as Aaron Wildavsky shows in his account of the thinking, researching, writing and rewriting that produced two major books.

In addition to articles of a more or less conventional format, the fournal will pursue its interest in relating ideas to practical problems by publishing under the heading of Ideas in Vogue: will they stand up? tough and fairminded analysis of ideas about policy making currently in vogue - whether among academics or practitioners - assessing whether they have the theoretical validity and the utility to justify their prominence.

Governments themselves are the sponsors of nuch policy-relevant research. Major government reports sometimes contain substantial research materials as appendices, or their contents can be reviewed to increase understanding of public policy beyond their specific recommendations. We will regularly 
publish under the heading of Research from the inside reviews of reports recently published by national governments or by the OECD, the European Community or other international bodies.

In selecting book reviezes, the fournal will typically review books by testing findings derived from one perspective against a reviewer normally working in another discipline, or in the same field in another country.

The tests for a good journal article are several: originality, relevance, breadth and clarity. The fournal of Public Policy invites policy analysts, whatever their subject matter or specific interest, to submit articles that can be measured by these criteria. 